\title{
Re-Presenting the Future of Medicine's Past: Towards a Politics of Survival ${ }^{1}$
}

\author{
ROGER COOTER*
}

Keywords: Epistemic Virtues; Postmodernism; Neoliberalism; Disciplinarity; Multidisciplinarity; Medical Humanities

The 'death' of the social history of medicine was predicated on two insights from postmodern thinking: first, that 'the social' was an essentialist category strategically fashioned in the course of the nineteenth and twentieth centuries; and second, that the disciplines of medicine and history-writing grew up together, the one (medicine) seeking to objectify the body, the other (history-writing) seeking to objectify the past. ${ }^{2}$ Not surprisingly, in the face of these revelations, historians of medicine retreated from the critical and 'big-picture' perspectives they entertained in the 1970s and 1980s. Their political flame went out, and doing the same old thing increasingly looked more like an apology for, than a critical inquiry into, medicine and its humanist project. Unable to face the present, let alone the future, they retreated from both, suffering the same paralysis of will as other historians stymied by the intellectual movement of postmodernism. Ironically, this occurred (occurs) at a moment when 'medicine' - writ large to include the biosciences and biotechnology - could easily be said to be the most relevant and compelling subject for understanding contemporary life and politics (global, local, and individual) and, as such, the place to justify the practice of history-writing as a whole. God knows, legitimacy has never been more urgent. ${ }^{3}$ But how can this be effected? Political action seems more likely than prayer. But let us begin by reviewing the nature of the problem that demands this response.

First and foremost is the 'audit culture' instrumentalised by today's managers of higher education. ${ }^{4}$ Nothing bears more fearfully than this on a professional practice that sometimes

(C) Roger Cooter, 2011.

* Roger Cooter, Professor, The Wellcome Trust Centre for the History of Medicine at UCL, 183 Euston Road, London NW1 2BE, UK. Email: r.cooter@ucl.ac.uk

\footnotetext{
${ }^{1}$ This paper draws on the final section of 'So What? Why Bother?', the Introduction to Roger Cooter, Medicine, Biomedicine, and the Politics of History, forthcoming.

${ }^{2}$ Roger Cooter, "After Death/After-"life": The Social History of Medicine in Post-Postmodernity" Social History of Medicine, 20 (2007), 441-64.

${ }^{3}$ See James Vernon, 'The End of the Public University in England', online: http://www.
}

\author{
insidehighered.com/blogs/globalhighered/ \\ the_end_of_the_public_university_in_england, accessed \\ 25 January 2011. \\ ${ }^{4}$ Michael Power, The Audit Society: Rituals of \\ Verification (New York: Oxford University Press, \\ 1997). The audit culture bears as much on the \\ sciences as on the humanities; as the historian of \\ science, Paul Forman, has noted, today 'the beau \\ ideal is no longer the "disinterested" scientist of \\ modernity, but the entrepreneur for whom success is \\ the only criteria of merit': '(Re)cognizing \\ Postmodernity: Helps for Historians - of Science \\ Especially', Bericht zur Wissenschaftsgeschichte, 33 \\ (2010), 7. See also, Karin Knorr Cetina, 'The Rise \\ of a Culture of Life', EMBO Reports, 6 (2005), \\ 76-80.
}




\section{Roger Cooter}

aspires 'to ask awkward questions, [rather than]... validate current assumptions'. 5 The recent cull (without peer review) of ancient historians, early-modernists, and medical historians in some British universities, and comparable exercises on American campuses, ${ }^{6}$ does not, however, reflect any fear of such awkward questioning on the part of the bureaucrats of higher education, for, in truth, there has been little of it among historians. Rather, more simply, it reflects the bureaucrat's inability to see the point of studying the past, and the inability of historians to convince them otherwise. ${ }^{7}$ Self-evident, on the other hand, are the practical virtues of business schools and science parks on university sites, since manifest income generation is the highest measure of 'utility' or 'practicality' within such a culture. Little understood by the bureaucrats or anyone else is that 'utility' and 'practicality' are but idealisations, and that the dichotomy between 'academic' and 'practical' or indeed, between 'the practical' and 'the idealistic' are but historical constructs sustained culturally, socioeconomically, and politically.

My point is not that university managers and their cronies in government and the funding councils are cretins, but rather that they operate according to certain epistemic virtues or values, like everyone else in the world (including historians). ${ }^{8}$ As confident products of the neoliberal marketplace, they follow their political orders in a culture that assumes economic utility to be the greatest virtue to which any human can aspire. ${ }^{9}$ Academics, being also of that market culture, follow suit and, compelled to compete against each other for ever-more remote research funds, collude in an unselfconscious re-scripting and re-valuing of their own practices. As the sociologist of science, Barry Barnes, has

\footnotetext{
${ }^{5}$ Richard Overy, 'The Historical Present', Times Higher Education, 29 April 2010, 34. Or, as Jeffrey Sammons puts it, what is in need of protection today is 'learning that disturbs and disrupts... that cannot be relied on for ulterior purposes and yet is wholly necessary for keeping open the options of being human, that cannot be defended on the grounds of what is it good for because no one can know what it is good for until it has been explored, examined, and weighed in each generation':

'Squaring the Circle' (1986), quoted in Robert Post, 'Debating Disciplinarity', Critical Inquiry, 35 (2009), 760.

${ }^{6}$ Anthony T. Grafton, 'Britain: The Disgrace of the Universities', New York Review of Books, 8 April 2010, 32; Simon Head, 'The Grim Threat to British Universities', New York Review of Books, 13 January 2011. See also, Martha Nussbaum, 'Skills for Life: Why Cuts in the Humanities pose a Threat to Democracy Itself,' Times Literary Supplement, 30 April 2010, 13. For the American situation, see 'Campus Cuts', and 'How the University Works', The Chronicle of Higher Education, 27 June 2010, at http://chronicle.com/blog/campuscuts/21.

${ }^{7}$ As Robert Rosenstone remarks, most scholarly works of history 'are written as if to cater only to those who already want to know about a particular subject and they write off the rest of the public. In the way they hang on to outmoded kinds of narrative and analysis, they seem to assume that you should care
}

about what they have to say, but they don't justify that assumption. History is good for you, they imply but they never say why. And if they don't answer that question, why would anyone else?': 'Space for the bird to fly', in Keith Jenkins, Sue Morgan and Alun Munslow (eds), Manifestos for History (London: Routledge, 2007), 17. Conventional historians just dig bigger and bigger holes for themselves in condemning postmodern trends without admitting to the subjectivity of their own practices and to their blind faith in 'objectivity'. Anthony Beevor, for example, the author of Stalingrad, rails at Hilary Mantel's phenomenally successful fictionalisation of the life of Thomas Cromwell - Wolf Hall (London: Fourth Estate, 2009) - on the grounds that this 'histotainment' and 'faction-creep' dangerously 'corrupts' the boundaries between fact and fiction, objectivist Truth and subjectivity - 'you just can't tell what's original any more': 'Eyes on the Prize', Intelligent Life, The Quarterly from The Economist, 4 (2010), 79. On the scientificity of historians, see Hayden White, 'The Public Relevance of Historical Studies: A Reply to Dirk Moses', History and Theory, 44 (2005), 333-8.

${ }^{8}$ On how scientists, past and present, make up scientific objectivity according to epistemic virtues, see Lorraine Daston and Peter Galison, Objectivity (New York: Zone Books, 2007).

${ }^{9}$ David Harvey, A Brief History of Neoliberalism (Oxford: Oxford University Press, 2005). 
noted in his field of study, "useful practices" now have greater value than. . knowing "for its own sake." 10 A decade or so ago that was not the case.

A further part of the problem is that the ideology of utility marches arm-in-arm with defences of history made on populist 'practical' grounds. Such defenses, often themselves married to reductive economic rationales, are hostile to the kind of critical historywriting that invokes 'theory'. ${ }^{11}$ What is forgotten in these accounts is that 'downto-earth' would-be 'theoryless' history-writing is itself always already in theory, always already in epistemology, including when it seeks to promote or refute any particular 'theory'. To disdain theory is a priori to have commitment to some kind of theory, as Terry Eagleton once remarked. ${ }^{12}$

What has been less commented on in the analysis of the public and professional problems facing history-writing today, is how academics in other fields often appropriate 'history' to bolster their own particular views and valuations of the world, and in so doing re-package and re-value the purpose of history. This move is perhaps most pronounced in the sociology of science and biomedicine - domains that in being more plugged into the 'real world' than academic history, tend to be furthur up the power chain of higher education. Nikolas Rose, for example, inheres history to lend credibility to his view of the 'greater complexity' of our biologised times, ${ }^{13}$ and hence to gain support for his further investigation into it. Another sociologist, Steve Fuller, rather more straightforwardly, uses history to promote the greatness of the logic of modern science, and to legitimise a new space for biology in sociology. That the disciplining of sociology c.1900 left biology out, Fuller contends, was merely the result of historical contingency; hence sociology can now be historically 'corrected'. ${ }^{14}$ In a 'knowledge economy' culture that only values knowledge with economic potential, such strategic uses of history - however cavalier, simplistic, and reductive - command far more respect and authority than 'purposeless' academic history. The considerable marketing success of various recent neurological reductions of history further instances this phenomenon, for these works purposively, if unselfconsciously, service the same set of values. ${ }^{15}$ Since sociologists and the new

\footnotetext{
${ }^{10}$ Barry Barnes 'Elusive Memories of Technoscience', Perspectives on Science, 13 (2005), quoted in Forman, op. cit. (note 4), 5.

${ }^{11}$ For example, Margaret Macmillan, The Uses and Abuses of History (London: Profile Books, 2009) who calls for historians to avoid 'theory'. As Joan W. Scott points out, 'theory' in such texts is associated with leftist politics, and 'objectivity' its antidote: 'History-Writing as Critique', in Jenkins, Morgan and Munslow (eds), op. cit. (note 7), 23.

${ }^{12}$ Terry Eagleton and Matthew Beaumont, The Task of the Critic: Terry Eagleton in Dialogue (London: Verso, 2009), 149.

${ }^{13}$ Nikolas Rose, The Politics of Life Itself (Princeton, NJ: Princeton University Press, 2007); for a rebuttal, see Roger Cooter and Claudia Stein, 'Cracking Biopower,' History of the Human Sciences, 23 (2010), 109-28.

${ }^{14}$ Steve Fuller, audio lecture, 'Warwick "Human Futures" Seminar on Chris Renwick's "Biology and the Making of British Sociology", 21 October 2010,
}

online: http://www2.warwick.ac.uk/fac/soc/sociology/ staff/academicstaff/sfuller/fullers_index/audio, accessed 25 January 2011. For Fuller's unblushing praise of the blatantly biological and neurological reductionist account of history proffered by Daniel Lord Smail (cited below), see his review in Interdisciplinary Science Review, 34 (2009), 389-92.

${ }^{15}$ For stunning examples, see David Lord Smail, On Deep History and the Brain (Berkeley, CA: University of California Press, 2008), and Iain McGilchrist, The Master and his Emissary: The Divided Brain and the Making of the Western World (New Haven, CT: Yale University Press, 2009). For various critical perspectives on contemporary 'braincentricity', see the essays in the special issue of History of the Human Sciences, 23 (2010); and Max Stadler, 'The Neuroromance of Cerebral History', 'The Neuroromance of Cerebral History', in Suparna Choudhury and Jan Slaby (eds), Critical Neuroscience: Between Lifeworld and Laboratory (Hoboken, NJ: Wiley-Blackwell, forthcoming). 


\section{Roger Cooter}

neurobiological reductionists of history can presumably write all the history that is needed for contemporary culture, why bother with funding professional historians at all - or, for that matter, history teaching anywhere in the educational curriculum? Herein lies the real 'end of history', and it is already well under way.

Connected to these developments are two further considerations bearing fundamentally on the practice and regard of history today - and more than a little on the history of medicine in particular. The first is the place of disciplinarity in the postmodern world; the second is 'postmodernity' itself. However, both these, if better understood, can hearken more optimistically for the future of history, for both can be politically turned around in its service.

Disciplinarity is now under siege, its identity, virtue, and function called into question, and its authority seriously challenged. Its assault - as on academic history - is made in part through the advocacy of 'interdisciplinarity' or 'multidisciplinarity' by those who control the purse strings of higher education. ${ }^{16}$ Multidisciplinarity is held to promote novel cross-fertilisation, something that in itself is held to be an inherent good. However, rather than promoting the disciplinarity it appears to presuppose, it surrenders it to a politically-correct sounding and thoroughly 'dissensus'-avoiding pluralism in which, crucially, all parties forfeit responsibility, thus leaving the managers of higher education to further extend their culturally nourished economistic and scientistic values and virtues. ${ }^{17}$ Interdisciplinarity, it should be understood, is not an evil in and of itself, although, that said, there is little evidence that the vaunted practice has ever produced anything truly novel or intellectually creative - least of all through collaborations between those in the natural sciences and those in the humanities. As Max Weber noted almost a century ago, it is only 'mediocrity' that mostly results from academics of different sorts trying to 'cooperate'. ${ }^{18}$ The problem, rather, is the political effect of the dogma of multidisciplinarity in absenting academics from the exercise of intellectual and ethical responsibility. Thus, for us now to assert disciplinarity is a means to reclaim that responsibility. It is an act that becomes political in the face of the pervasive and aggressive politics of the disappearance of disciplinarity.

I didn't always think so; like others in the 1970s and 1980s, I negatively associated 'discipline' with punishment and constraint, and came to regard academic disciplines in general as relics of modernity. I was not alone in thinking that under the emergent conditions of 'postmodernity' a discipline whose boundaries were only lightly policed was the best of all. In part, it was because of this relative openness that the history of medicine was exempted from the charge of 'disciplinary blindness' or 'single vision' that some American historians levelled at their colleagues in the wake of the challenges

\footnotetext{
${ }^{16}$ Interdisciplinarity has been described by the sociologist Peter Weingart as, at best, the 'result of opportunism in knowledge production'. Peter Weingart, 'Interdisciplinarity: The Paradoxical Discourse', in Peter Weingart and Nico Stehr (eds), Practising Interdisciplinarity (Toronto: University of Toronto Press, 2000), cited in Post, 'Debating Disciplinarity', op. cit. (note 5), 755. See also James Chandler, 'Introduction: Doctrines, Disciplines, Discourses, Departments', Critical Inquiry, 35 (2009), 739-40.
}

\footnotetext{
${ }^{17}$ On the merits of 'dissensus' over intellectual consensus, see Jacques Rancière, Aesthetics and its Discontents (Cambridge: Polity Press, 2009), $115 \mathrm{ff}$.

${ }^{18}$ Max Weber, 'Science as a Vocation' (1918), http://www.ne.jp/asahi/moriyuki/abukuma/weber/ lecture/science_frame.html, accessed 25 January 2011, 3, see also 12 on modern medicine and its humanist presuppositions.
} 


\section{Re-Presenting the Future of Medicine's Past}

from the literary turn. ${ }^{19}$ Given how the latter turn privileged the body as a site for the discursive analysis of modernity, it helped the history of medicine that 'the body' was ostensibly a part of its remit. ${ }^{20}$ Although, actually, the social history of medicine was far from in the van of the 'somatic turn', it could at least ride on (or hide behind) a boasted methodological pluralism. In fact, fearful of 'postmodern postures', the history of medicine continued to believe in the virtues of the social politics upon which it had been reared as a profession within history departments in the 1960s and 1970s. Those were its politics, and they were relevant to, and productive within, the context of the sub-discipline's creation. They were what animated and gave it vitality. But as those politics dried up in the context of an entwined postmodernity and neoliberalism, ${ }^{21}$ and social history's structuralist-instrumentalist understanding of power evaporated, the sub-discipline increasingly found itself unable to distinguish its wares from those of populist history. In effect, it became little more than populist history in academic dress, defending notions of change and other Enlightenment/modernist tasks that were embedded in its construction. Every 'cultural turn' it struggled to make only served further to betray the original political animus. ${ }^{22}$

The need to re-politicise through the device of advocating disciplinarity is all the more urgent in the history of medicine today in the face of one particularly virulent form of multidisciplinarity: 'medical humanities'. As re-branded on American campuses over the past few decades, and now promoted by the Wellcome Trust in the UK (hitherto the principal funder of the history of medicine), medical humanities aspires to provide a consortium for all manner of parties interested in biomedicine, thus diluting, if not subverting, any critical contribution from historians. Historians, as unequal partners in this forum (unequal because the forum is owned by those promoting biomedicine), are valued mainly as the suppliers of witness statements to biomedicine's 'progress', and hence, as allies in medicine's project of medical humanism. Thus, the history of medicine becomes but a market device for the 'greatness' of biomedicine and medical philanthropy.

If academic history is to be maintained as something different and distinct from both populist apology and the sale of the interconnected epistemic virtues of scientists, sociologists, and business managers, its practitioners need to do more than merely agree on 'the rules that govern their discourse'. ${ }^{23}$ In order to assert disciplinarity in the face of the politics for its disappearance, they need first to understand how the challenge to

\footnotetext{
${ }^{19}$ Roger Cooter, 'The Traffic in Victorian Bodies: Medicine Literature and History', Victorian Studies, 45 (2003), 513-27.

${ }^{20}$ Roger Cooter, 'The Turn of the Body: History and the Politics of the Corporeal', Arbor Ciencia, Pensamiento y cultur, 186 (2010), 393-405.

${ }^{21}$ See: David Harvey, A Brief History of Neoliberalism (Oxford: Oxford University Press, 2005); and Luc Boltanski and Eve Chiapello, The New Spirit of Capitalism, Gregory Elliott (trans.), (London: Verso, 2005).

${ }^{22}$ See, for example, the concluding pages of Mary Fissell, 'Making Meaning from the Margins: The New Cultural History of Medicine' in Frank Huisman
}

and John Harley Warner (eds), Locating Medical History: The Stories and their Meanings (Baltimore, MD: Johns Hopkins University Press, 2004), 364-89.

${ }^{23}$ Which is precisely what Kuhn asserted in the 1960s for the continued practice of science in the face of his own exposure of it as socially and culturally contingent: Kuhn, quoted in Georg Iggers, Historiography in the Twentieth Century: From Scientific Objectivity to the Postmodern Challenge (Hanover: Wesleyan University Press, 1997), 120. For Iggers this was not a necessary move for historians in the 1990s. Such, I hazard, is the difference between his times (fighting the literary turn) and ours (fighting for survival). 


\section{Roger Cooter}

disciplinarity and the anxieties flowing from it have come to be constituted and embodied in themselves.

To this end, it is worth grasping the crucial distinction that has recently been wrought by the historian of science Paul Forman - between postmodernism as a body of thought critical of modernity, and postmodernity as an era. Once this distinction is lodged, and postmodernism is no longer perceived as the cause of the postmodern era, it becomes possible to shake off the ennui to which a seemingly fearful and threatening postmodernism has given rise in the history profession. Not in the politics but in the spiritedness of the 1960s-to-1980s, we might begin to re-formulate ethical-critical positions on the era of postmodernity in which we live, and begin seriously to excavate its material, economic, and cultural workings, not least upon history-writing, and not least upon biomedicine in relation to the intellectual movement of postmodernism and the culture and politics of neoliberalism. The need for historians to retreat to modernist ('social') positions and practices, or worse, attempt to mount reactionary defences against postmodernism (as in the 'new empiricism' in history-writing) can be dispensed with.

Through understanding the distinction between postmodernity and postmodernism, faith in critique as the ultimate purpose of history writing can be regained, perhaps along with belief in historical wisdom. ${ }^{24}$ Effective resistance can then be mounted against the appropriation, devaluation, de-skilling, and abuse of academic history in a neoliberal culture that privileges 'utilitarian individualism'. Intellectual and moral commitment to the practice of history-writing and to its community can then be reasserted on grounds other than those of pious hope, such as recently tendered by the historian of medicine, Charles Rosenberg. ${ }^{25}$ For a history of medicine writ large - now extending to embrace and to challenge the future of all humanity and the humanities - the move is essential. Prayers for survival simply won't suffice, and are daily proven useless.

\footnotetext{
${ }^{24}$ On the value of critique, see Judith Butler, 'Critique, Dissent, Disciplinarity', Critical Inquiry, 35 (2009), 773-95; and Scott, op. cit. (note 11), 19-38. On historical wisdom, see W.T. Mitchell, 'Art, Fate, and the Disciplines: Some Indicators', Critical Inquiry, 35 (2009), 1026-7.

${ }^{25}$ Although Rosenberg is one of the few historians of medicine to express in print the current need to pause over the shared values and assumptions
}

of fellow practitioners, he can only assert that 'To be effective historians must maintain their disciplinary identity, their own criteria of achievement and canons of excellence': 'Anticipated Consequences: Historians, History, and Health Policy', in his Our Present Complain: American Medicine, Then and Now (Baltimore, MD: Johns Hopkins University Press, 2007), 203. 